\title{
The impact of economic crisis on cost structure configuration
}

\author{
Odysseas Pavlatos* \\ Department of Accounting and Finance, University of Macedonia, Greece
}

Received: 12 February 2020

Revised: 25 June 2020

Accepted: 29 July 2020

\begin{abstract}
The objective of this study is to examine the impact of economic crisis on cost structure configuration of companies. For this reason, an empirical study in the form of online survey has been carried out in 82 Greek manufacturing companies. We received data from two periods of great economic recession, namely during fall of 2013 and spring of 2015. Results indicated that companies most affected by the economic crisis, replaced fixed costs with variable ones. Cost structure configuration is the "tool" that companies used to limit the consequences of the crisis in their profitability.
\end{abstract}

Keywords: economic crisis, cost structure, fixed costs, variable costs

JEL Classification Codes: M20, M21, M42

\section{Introduction}

The economic crisis constitutes a substantial threat for companies, and it is associated with the lack of resources, increased uncertainty, as well as little time of response (Janke et al., 2014). This type of crisis rises cash flow issues and it minimizes profits and sales for businesses (Williams and Kayaoglu, 2020; Becker et al., 2016). Despite the literature callings, cost and management accounting research provides a restricted guidance on how companies can manage the economic crisis (Van der Stede, 2011; Hopwood, 2009).

Previous studies indicated that there is an association between economic crisis and the utilisation of management accounting techniques. In specific, Janke et al. (2014) have ascertained that companies most affected by the crisis, use Management Control Systems more than other companies in order to deal with it. Similarly, Pavlatos and Kostakis (2018) found that there is a positive association between the economic crisis and the use of management accounting innovations. Furthermore, Becker et al. (2016) established that companies most affected by the crisis consider budgets to be more important for planning and resource allocation and less important for performance evaluation purposes.

The cost structure and its behaviour are a considerable subject of study, both of accounting as well as of economic literature (Drury, 2012). The cost structure configuration definition of

\footnotetext{
* Corresponding author. E-mail: opavlatos@uom.edu.gr.

Citation: Pavlatos, O. (2021) The impact of economic crisis on cost structure configuration, Economics and Business Letters, 10(1), 87-94.
}

DOI: $10.17811 / \mathrm{ebl} \cdot 10.1 .2021 .87-94$ 
firms, that constitutes a management decision, is referred to the fixed or variable costs' percentage over the total companies' costs (Garrison et al., 2011). The cost structure is associated with the companies' profitability (Drury, 2012). Companies with multiple fixed costs exhibit an increased operating leverage, thus their profitability fluctuates more due to changes in sales (Garrison et al., 2011).

Hopwood (2009) notes that economic crisis resulted in an intensification of financial information flows within companies. Due to the uncertainty that the economic crisis has created, more and better cost accounting information is needed to reduce this uncertainty (Pavlatos and Kostakis, 2018). As a result, the decision-making process is improved, and management control becomes more effective (Pavlatos and Kostakis, 2018). Previous studies (Becker et al., 2016; Janke et al., 2014) report that economic crisis affects management decisions (e.g. budgeting, management control) taken by firms to deal with it. According to Pavlatos and Kostakis (2015) the decline in sales caused by the economic crisis is likely to affect companies' decision to configure their costs in order to survive. Companies that have been affected the most by the economic crisis, it is possible to decide to reduce the operating leverage ratio in order to be more secure and less sensitive to sales variations (Pavlatos and Kostakis, 2015).

In this study, we aim to explore whether there is any association between the impact of economic crisis and the cost structure configuration of the companies. We deem likely that companies most affected by the economic crisis, chose to reshape their cost structure, replacing fixed costs with variable ones. In this way, they manage to lesser reduce their profitability due to sales decrease caused by the economic crisis.

Therefore, we formulated the following research hypothesis:

H1: Companies more highly impacted by an economic crisis increase the percentage of variable costs in their total costs.

The structure of the study is the following. In the next section, we present the study methodology. In the third section we introduce its results, while in the last section we point out the findings and we provide guidance for future studies.

\section{Methodology}

In order to study the economic crisis' perception in the cost structure formation of companies, an empirical study in the form of online survey has been carried out in Greek manufacturing companies. Greece is a country that has been highly impacted by the economic crisis that began in 2010 and become more prominent during 2013-2015 (Pavlatos and Kostakis, 2015). The reason why this sector is chosen in this paper, is the fact that, according to previous studies, the said sector had the highest degree of impact caused by economic crisis in the country (Pavlatos and Kostakis, 2018).

The survey has been sent to the 450 largest manufacturing companies, based on the number of employees, according to the ICAP database (Gallup's subsidiary in Greece).

We received data from two periods of great economic recession, namely during fall 2013 and spring 2015. The final sample comprises only those companies that participated in both surveys (2013 and 2015). Ultimately, 82 questionnaires have been collected, equal to $18 \%$ response rate. The surveys have been filled by the CEOs of the companies. The representativeness of the sample has been checked in accordance with the population, and no significant statistical differences have been observed concerning the number of employees or the $5 \%$ of the sub-industries' sector. We also checked whether there are differences between early and late respondents, while the statistical analysis did not indicate any significant statistical differences at the 5\% level. In Table 1 we illustrate the descriptive characteristics of the companies participating in the study. 
Table 1. Demographic characteristics of the business units that participated in the survey.

\begin{tabular}{lrr}
\hline \hline Panel A: Size (No of employees) & N & \% \\
\hline $200-350$ & 38 & 46 \\
$351-500$ & 25 & 30 \\
$501-650$ & 10 & 12 \\
$651-800$ & 5 & 6 \\
$801-950$ & $4 \frac{4}{2}$ & $\underline{5}$ \\
Panel B: Sub industry & & 100 \\
Food & 22 & 27 \\
Beverages & 15 & 18 \\
Oil & 8 & 10 \\
Minerals & 8 & 10 \\
Basic metals & 6 & 7 \\
Drugs & 6 & 7 \\
Tobacco & 5 & 6 \\
Electronic/ electrical equipment & 5 & 6 \\
Paper & 1 & 1 \\
Other & $\underline{6}$ & $\underline{7}$ \\
& 82 & 100 \\
\hline \hline
\end{tabular}

Table 2. Definition of variables used in the study.

\begin{tabular}{|c|c|}
\hline Construct / Variable & Measurement \\
\hline Cost structure & $\begin{array}{l}\text { Percentage of their variable costs to the total costs for both periods (2013- } \\
\text { 2015). }\end{array}$ \\
\hline Crisis' pe & $\begin{array}{l}\text { Six-items Likert scale anchored by (1) No extent to (7) Great extent. } \\
\text { Items: } \\
\text { 1. To what extent is your business unit impacted by the economic cri- } \\
\text { sis? } \\
\text { 2. Have orders declined? } \\
\text { 3. Have sales declined? } \\
\text { 4. Have customers increasingly failed to pay? } \\
\text { 5. Have suppliers increasing been unable to provide good? } \\
\text { 6. Has been a reduction in capital availability? }\end{array}$ \\
\hline PEU & $\begin{array}{l}\text { Four- items Likert scale anchored by (1) Totally disagree to (7) Totally agree. } \\
\text { Items: } \\
\text { 1. The external environment of your business unit is rapidly changing. } \\
\text { 2. Many new products in the industry have been marked during the past } \\
5 \text { years. } \\
\text { 3. It is becoming more difficult to predict the market activities of your } \\
\text { competitors during the past } 5 \text { years. } \\
\text { 4. It is becoming more difficult to predict the tastes and preferences. }\end{array}$ \\
\hline Strategy & $\begin{array}{l}\text { Single item measure ranging from (1) Cost leadership to (7) Product differ- } \\
\text { entiation. }\end{array}$ \\
\hline Size & Natural logarithm of the number of employees. \\
\hline Life cycle stage & $\begin{array}{l}\text { Consists of } 5 \text { stages: (1) formation/birth, (2) growth, (3) mature stage, (4) } \\
\text { realignment/revival and (5) decline. }\end{array}$ \\
\hline
\end{tabular}

In order to measure the cost structure, the companies' CEOs were asked to indicate the percentage of their variable costs to the total costs of the company for both periods (2013-2015). Crisis' perception has been measured via a six-item Likert scale anchored by (1) No extent to (7) Great extent, according to previous studies (Janke et al., 2014; Becker et al., 2015). The said 
Table 3. Descriptive statistics of economic crisis' perception.

\begin{tabular}{lcccc}
\hline \hline & Mean & S.D & Min & Max \\
\hline $\begin{array}{l}\text { 1.To what extent is your business unit im- } \\
\text { pacted by the economic crisis? }\end{array}$ & 5.72 & 1.48 & 2 & 7 \\
$\begin{array}{l}\text { 2.Please indicate to what extent your busi- } \\
\text { ness unit faces the following impacts of the }\end{array}$ & & & & \\
economic crisis: & & & & \\
$\quad \begin{array}{l}\text { a. Have orders declined? } \\
\text { b. Have sales declined? }\end{array}$ & 5.89 & 1.78 & 2 & 7 \\
c. Have customers increasingly failed & 5.92 & 1.85 & 3 & 7 \\
$\quad$ to pay? & 5.24 & 1.43 & 2 & 7 \\
d. Have suppliers increasing been una- & 5.29 & 1.78 & 2 & 7 \\
$\quad$ ble to provide good? & & & \\
$\quad$ Has been a reduction in capital avail- & 5.25 & 1.94 & 2 & 7 \\
$\quad$ ability?
\end{tabular}

construct measures the perception of the CEOs relatively to the effect extent of the economic crisis on their companies. Perceived Environmental Uncertainty- PEU has been measured using a four- item Likert scale anchored by (1) Totally disagree to (7) Totally agree according to Pavlatos and Kostakis (2018). Strategy was measured with a sing item question which asks the respondents to indicate which best describes their view on the firms' strategic emphasis, ranging from (1) Cost leadership to (7) Product differentiation. Respondents were asked to assess the lifecycle of their company on a single item 5-point Likert scale. The lifecycle consists of 5 stages: formation/birth, growth, mature stage, realignment/revival and decline. Higher values mean more mature firms. Size was measured using the natural logarithm of the number of employees. Both the selection and measurement of these variables have been performed according to previous studies (e.g. Janke et al., 2014; Becker et al., 2015). Economic crisis perception and PEU were measured as reflective constructs. These variables have been constructed by factor analysis as the factor loadings. Table 2 presents the definition of variables used in the study.

In Table 3 we illustrate the descriptive statistics of economic crisis' perception. In this study, business strategy, size, Perceive Environmental Uncertainty - PEU, as well as, lifecycle stage was used as control variables

\section{Results}

The data analysis has been carried out according to the Partial Least Squares (PLS) method. Table 4 illustrates a statistically significant mean value percentage increase in variable costs over total costs between 2013 and 2015. Table 5 presents the remaining descriptive statistics of the study's variables. The correlations among variables are low, leading to the conclusion that multicollinearity is not an issue (Table 6). The Internal Composite Reliability (ICR), as well as Cronbach's Alpha and Average Variance Extracted (AVE) values for all constructs prove that they possess sufficient reliability (Table 7). The discriminant validity was also acceptable, as the AVE was greater than the squared correlation in all constructs. To assess the validity of the survey-based crisis' perception, we received info about the sales and Earnings before interest and taxes (EBITs) of all companies participating in the survey by the ICAP Data Prisma and we found out that all companies underwent a decrease in sales and EBITs between 2013 and 2015. We also observed that there is a positive and significant association between the economic crisis' perception and EBIT decrease, as well as sales decrease, leading to the conclusion that the crisis; perception measurement is valid (Table 8). 
Table 4. Descriptive statistics and mean difference of cost structure (2013-2015).

\begin{tabular}{lcccrrrr}
\hline \hline & \multicolumn{2}{c}{2013} & \multicolumn{2}{c}{$\mathbf{2 0 1 5}$} & & & \\
& Mean & S.D & Mean & S.D & $\begin{array}{r}\text { Mean } \\
\text { Difference }\end{array}$ & t - value & Sig. \\
\hline $\begin{array}{l}\text { Cost structure } \\
\text { (\% of variables costs) }\end{array}$ & 43.23 & 10.05 & 56.48 & 10.72 & 13.25 & 12.201 & 0.001 \\
\hline \hline
\end{tabular}

Table 5. Descriptive statistics of the mean scores of the variables and multi-items measures.

\begin{tabular}{|c|c|c|c|c|c|c|c|}
\hline Variable & $\mathbf{N}$ & Mean & $\begin{array}{r}\text { Std. } \\
\text { Deviation } \\
\end{array}$ & $\begin{array}{r}\text { Theoretical } \\
\text { Minimum }\end{array}$ & $\begin{array}{r}\text { Theoretical } \\
\text { Maximum }\end{array}$ & $\begin{array}{r}\text { Actual } \\
\text { Minimum }\end{array}$ & $\begin{array}{r}\text { Actual } \\
\text { Maximum }\end{array}$ \\
\hline Cost structure ${ }^{a}$ & 82 & 10.24 & 2.82 & - & - & 5.25 & 19.24 \\
\hline $\begin{array}{l}\text { Economic crisis' } \\
\text { perception }\end{array}$ & 82 & 5.56 & 1.71 & 1 & 7 & 2 & 7 \\
\hline $\begin{array}{l}\text { Control } \\
\text { variables: }\end{array}$ & & & & & & & \\
\hline Strategy & 82 & 5.12 & 0.58 & 1 & 7 & 1 & 7 \\
\hline$P E U$ & 82 & 5.35 & 0.68 & 1 & 7 & 2 & 7 \\
\hline $\begin{array}{l}\text { Size } \\
\text { (No of employees) }\end{array}$ & 82 & 402.24 & 58.24 & 200 & - & 201 & 912 \\
\hline Lifecycle stage & 82 & 2.88 & 0.18 & 1 & 5 & 2 & 5 \\
\hline
\end{tabular}

Note: ${ }^{\mathrm{a}}$ mean difference $2013 \kappa \alpha 12015,{ }^{\mathrm{b}}$ measured with natural logarithm of the number of employees.

Table 6. Correlations from PLS model $(\mathrm{n}=82)$.

\begin{tabular}{lrrrrrr}
\hline \hline \multicolumn{1}{c}{ Variable } & $\mathbf{1}$ & $\mathbf{2}$ & $\mathbf{3}$ & $\mathbf{4}$ & $\mathbf{5}$ & $\mathbf{6}$ \\
\hline 1. Cost structure & 1 & & & & & \\
2. Economic crisis & 0.26 & 1 & & & & \\
perception & $*$ & 1 & & & & \\
3. Strategy & 0.23 & 0.19 & 1 & & & \\
4. PEU & 0.22 & 0.21 & 0.24 & 1 & & \\
5. Size & $*$ & & & & \\
6. Lifecycle stage & 0.24 & 0.22 & 0.25 & 0.12 & 1 & \\
\hline \hline
\end{tabular}

Note: * indicates Correlations is significant at the .05level (2 tailed).

To assess the structural model, we calculated the $\mathrm{R}^{2}$ value for the endogenous variable (cost structure), which was $25.8 \%$, quite higher than the $10 \%$ threshold (Hair et al., 2017). In addition, the Stone - Geisser $\mathrm{Q}^{2}$ value for the cost structure was greater than zero, and as a result the model prediction capacity is sufficient (Hair et al., 2017). Moreover, there has been a collinearity control for the independent variable of the economic crisis' perception, and we found out that the Variance Inflation Factor (VIF) 1.135 is significantly lower than the acceptable threshold (5) (Hair et al., 2017). The statistical analysis indicated that the economic crisis' perception has a positive and statistically significant effect in cost structure $(\beta=0.296, p$-value $=$ 0.001 ), resulting in the H1 hypothesis support (Table 9). As far as the control variables are concerned, it has been established that only size has a positive and statistically significant effect in cost structure $(\beta=0.212$, $p$-value $=0.029)$ (Table 9$)$. Due to the cross-sectional character of the data, no claims of causality can be made. In order to confirm the robustness of our results, we used ordinal regression analysis, and we concluded similar results. Moreover, we tried to construct and test a variable containing only the five (possible) specific crisis effects on cost structure, and we also concluded similar findings. 
Table 7. Reliability and validity analysis of multi-items constructs $(\mathrm{n}=82)$.

\begin{tabular}{|c|c|c|c|c|c|}
\hline & $\mathbf{I C R}^{\mathrm{a}}$ & Alpha $^{\text {b }}$ & $\overline{\mathbf{A V E}^{\mathrm{c}}}$ & Item & Loading \\
\hline \multirow[t]{6}{*}{$\begin{array}{l}\text { Crisis' } \\
\text { perception }\end{array}$} & 0.867 & 0.824 & 0.644 & $\begin{array}{l}\text { To what extent is your business unit im- } \\
\text { pacted by the economic crisis? } \\
\text { Please indicate to what extent your business } \\
\text { unit faces the following impacts of the eco- } \\
\text { nomic crisis: }\end{array}$ & 0.831 \\
\hline & & & & Have orders declined? & 0.822 \\
\hline & & & & Have sales declined? & 0.794 \\
\hline & & & & Have customers increasingly failed to pay? & 0.801 \\
\hline & & & & $\begin{array}{l}\text { Have suppliers increasing been unable to } \\
\text { provide good? }\end{array}$ & 0.744 \\
\hline & & & & Has been a reduction in capital availability? & 0.782 \\
\hline \multirow[t]{4}{*}{$P E U$} & 0.829 & 0.825 & 0.669 & $\begin{array}{l}\text { The external environment of your business } \\
\text { unit is rapidly changing }\end{array}$ & 0.812 \\
\hline & & & & $\begin{array}{l}\text { Many new products in the industry have } \\
\text { been marked during the past } 5 \text { years }\end{array}$ & 0.795 \\
\hline & & & & $\begin{array}{l}\text { It is becoming more difficult to predict the } \\
\text { market activities of your competitors during } \\
\text { the past } 5 \text { years }\end{array}$ & 0.824 \\
\hline & & & & $\begin{array}{l}\text { It is becoming more difficult to predict the } \\
\text { tastes and preferences of your customers } \\
\text { during the past } 5 \text { years }\end{array}$ & 0.831 \\
\hline
\end{tabular}

Notes: ${ }^{\mathrm{a}}$ Internal composite reliability; ${ }^{\mathrm{b}}$ Cronbach's alpha; ${ }^{\mathrm{c}}$ Average variance extracted

Table 8. Validity of survey based economic crisis' perception.

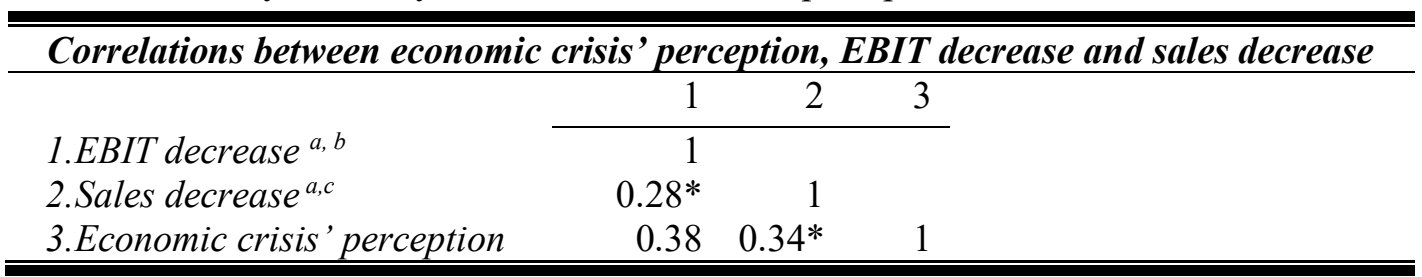

Notes: ${ }^{\text {a }}$ The analysis of Sales and EBIT comprise the subsample of the business units participated in the survey, could be retrieved from ICAP Data Prisma database, ${ }^{\mathrm{b}}$ EBIT decrease = (EBIT 2015EBIT 2013)/ EBIT $2013 \cdot(-1),{ }^{\mathrm{C}}$ Sales decrease = (Sales 2015-Sales 2013)/ Sales $2013 \cdot(-1)$, * indicates correlations are significant at the .05level (2 tailed)

Table 9. Results from PLS analysis $(\mathrm{n}=82)$.

\begin{tabular}{|c|c|c|c|}
\hline Path to: & \multicolumn{2}{|c|}{ Cost structure $^{\mathrm{a}}$} & Test of Hypothesis \\
\hline Path from: & Path coefficient & p values & \\
\hline $\begin{array}{l}\text { Economic crisis' perception } \\
\text { Control variables }\end{array}$ & 0.296 & 0.001 & H1 supported \\
\hline$P E U$ & 0.151 & 0.128 & \\
\hline Size & 0.212 & 0.029 & \\
\hline Strategy & 0.018 & 0.209 & \\
\hline Lifecycle stage & 0.189 & 0.085 & \\
\hline & $\mathrm{R}^{2}=0.258$ & & \\
\hline
\end{tabular}

Notes: ${ }^{a}$ mean difference 2013 and 2015 


\section{Conclusions and discussion}

Data from fiscal year 1999 to fiscal year 2019 (Bangladesh Bank, 2019) shows that the real rate Results indicated that there is a positive association between the economic crisis' perception and the cost structure configuration. Companies that have been affected the most by the economic crisis, justify their cost structure, increasing the variable costs' percentage, while simultaneously decrease the fixed costs' percentage over their total costs. This way, companies make an effort to reduce their profit decrease due to decrease in sales, as a result of the economic crisis. Companies that have been affected the most by the economic crisis, choose to reduce the operating leverage ratio in order to be more secure and less sensitive to sales variations. With this management decision, companies that have been affected the most by the crisis now need a smaller sales' value in order to reach the break-even point. Reconfiguring the cost structure, by replacing fixed costs with variable costs, is the "tool" that companies use to limit the consequences of the crisis in their financial results.

To the best of our knowledge, this study is the first empirical evidence of the relationship between the economic crisis and the cost structure configuration. This research has its limitations. The study generalises companies of different nature under the umbrella of manufacturing companies. Future studies could focus on specific type of companies to understand whether there are differences. This also qualitative to understand more and gain deeper insights. Furthermore, a fundamental limitation of this study is that data come from only one country, therefore any findings are limited solely to this country, that has been extensively impacted by the economic crisis. In addition, all data come exclusively from the manufacturing sector. Selecting a single sector ensures the validity of results. Future research could also investigate the cost structure changes of companies in different macroeconomics factors, such as the Gross Domestic Product. Moreover, to examine the impact of specific crisis components of economic crisis (e.g. sales decline, orders decline) on cost structure configuration. Finally, to investigate the possible effect of Perceived Environmental Uncertainty - PEU (specific items of PEU) on cost structure configuration. PEU is different type of uncertainty in comparison with economic crisis and needs to be examined (Becker et al., 2016).

This research findings can help business executives as it presents them with actions in response to economic crisis. Cost structure configuration is the "tool" that managers can use to limit the consequences of the financial crisis in their profitability, by increasing the variable costs' percentage over their total costs. The study indicates that managers have to recognize the importance of receiving sophisticated cost accounting information from cost management systems during periods of economic crisis.

\section{References}

Becker, S., Mahlendorf, M., Schäffer, U. and Thaten M. (2016) Budgeting in Times of Economic Crisis, Contemporary Accounting Research, 33 (4), 1489-1517.

Drury, C. (2012) Management and Cost Accounting, $8^{\text {th }}$ Edition, Cengage Learning: Boston. Garrison, R., Noreen, E. and Brewer, P. (2011) Managerial Accounting, McGraw-Hill: New York.

Hair, J. F., Jr., Hult, G. T. M., Ringle, C. and Sarstedt, M. (2017) A primer on partial least squares structural equation modeling (PLS-SEM), Sage Publications, CA: Los Angeles.

Hopwood, A. G. (2009) The economic crisis and accounting: Implications for the research community, Accounting, Organizations and Society, 34 (6-7), 797-802.

Janke, R., Mahlendorf, M. and Weber, J. (2014) An exploratory study of the reciprocal relationship between interactive use of management control systems and perception of negative external crisis effects, Management Accounting Research, 25 (4), 251-270. 
Pavlatos, O. and Kostakis, X. (2018) Management Accounting Innovations in a time of economic crisis, Journal of Economic Asymmetries, Vol. 18 (November), doi: https://doi.org/10.1016/j.jeca.2018.e00106

Pavlatos, O. and Kostakis, X. (2015) Management Accounting Practices before and during economic crisis: Evidence from Greece, Advances in Accounting, 31 (1), 150-164.

Van der Stede, W.A. (2011) Management accounting research in the wake of the crisis: some reflections, European Accounting Review, 20 (4), 605-623.

Williams, C.C. and Kayaoglu, A. (2020) COVID-19 and undeclared work: impacts and policy responses in Europe, The Service Industries Journal, doi: 10.1080/02642069.2020.1757073 